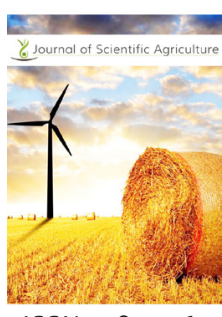

ISSN: $2184^{-0} 0261$

Received: April 04,2020 Accepted: May 05,2020 Published: May 17, 2020

*Corresponding Author: Akintobi

E-mail: akintobiolanrewaju@ gmail.com

Telephone: +2347088246184

\section{Analysis of the management competencies of goat farmers in some selected local government area of Lagos State Nigeria}

\author{
O.S. Akintobi ${ }^{*}$, B.C. Achu \\ Department of Agricultural Extension and Rural Sociology, University of Abuja, Nigeria
}

\begin{abstract}
This study focused on the analysis goat farmers' management competency in ensuring sustainable production in some selected local government areas of Lagos state, Nigeria. A total of 80 goat farmers were sampled for the study with the aid of structured questionnaires which were used to collect data needed for the study. The objectives of this study were analyzed using descriptive statistics and the hypothesis was tested using binary logistic regression. The result showed that men dominated women in goat farming and that the average age of respondents was 42.4 years. It revealed that majority of the respondents (65.4\%) made an annual income of 100,000-300,000 annually and had lived in the study area for $10-15$ years. This study also showed that majority of the respondents practiced semi intensive system of management, used family labour (55.6\%), the study further revealed that the goat farmers in the study area has low management competency with poor extension service, lack of pasture and graze land and prevalence of ectoparasite among the major challenges facing the goat farmers. It was recommended that farmers be encouraged to belong to organizations such as cooperatives to solve problems in management and government should revamp the extension service to improve service delivery to the farmers.
\end{abstract}

KEYWORDS: Goat farming, Management Competency, challenges, sustainable production.

\section{INTRODUCTION}

Management Competency is the knowledge, skills, attitude and judgment which one requires to perform successful at a specific level in any given task. With reference to this study, competencies are the knowledge, skills and attitude in goat production [1]. Asogwa, (2013) described goat as one of the livestock animals, scientifically known as Capra aegragus species, belonging to a family of Bovidae and genus capra. Goat as a ruminant animal is characterized by enlarged four stomachs rumen, reticulum, omasum and abomasums, which endow them with the ability to utilize forage and non-protein nitrogenous substances to produce meat, milk, skin and hair. Friday [2] (2004) observed that West African dwarf goat is mostly common and useful in Nigeria because of its resistance to trypanasomiasis and prolificacy [1] (Asogwa, (2013).

Goat production in Nigeria requires competency in various technical skills in order to keep and raise goat from parturition to adult ready for slaughter or marketing. Goat production requires skill in planning, site selection, site preparation, breeding, management practices, diseases control, feeding, marketing etc. [3] (Ogba, 2013). In the view of Boniface et al. [4], goat farmers require skills in planning, housing, feeding husbandry, disbudding, castration, disease control, breeding, record keeping, marketing etc. The need for management skills in agriculture in the world of today can never be over emphasized, Nigeria's population growth is continuously accelerating with unemployment rate at its all time high. Khalid [5] has it that there is just about an average of $28 \%$ of able-bodied individuals engaging in agricultural related jobs even as the white-collar jobs are very scarce. This problem could be attributed to the general poverty level of the country which hampers individuals from securing capital for farming and lack of the technical skills required to go into productive agriculture such as goat production. There seems to be a gap between the sustainable production and the skills needed for agricultural production as regards to goat production especially as goat is of higher demand than the supply in Nigeria due to continuous protein need by the people. This study therefore analyzes goat farmers' management competency in ensuring sustainable production of goat products to meet the protein demand level in the study area. The main objective of this research is to analyze management competency of goat farmers 
in Epe and Ikorodu local government area of Lagos State. However, the specific objectives are to

- Examine the socio-economic characteristics of goat farmers in the study area,

- Assess the level of competence of management practices of goat farmers in the study area,

- Identify the constraints faced by goat farmers in the study area.

The hypothesis of the study is stated in null form: "There is no significant relationship between the institutional characteristics and their level of competence of management practices of goat farmers".

\section{Methodology}

The study was carried out in Epe and Ikorodu local government area in Lagos State, the state lies between Longitude $3^{\circ} 58^{\prime}$ $43 \mathrm{E}$ and Latitude $06^{\circ} 353 \mathrm{~N}$ of the Equator. The population of this study comprised of all goat farmers in Epe and Ikorodu Local Government Areas of Lagos State. Multi-stage sampling technique was employed in sample selection. Purposive sampling was employed in the first stage which involved the selection of four communities each from two pre-selected local govern government (Odo-iragunshin, Noforija, Odomola, Iyare from Epe. while Gberigbe, Imota, Odogunyan. Oke ijebu from Ikorodu) and they were chosen because goat farming is prominent in these communities. The second stage involved using simple random sampling to select ten goat farmers from each of the communities to make up a sampling population of 80. Structured questionnaire was used through field survey and farmers interview.

The hypothesis was analyzed using binary logistic regression.

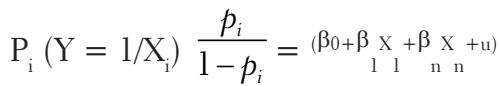

Where:

$$
\mathrm{y} \quad=\text { Competence level of Goat farmers }
$$

$\mathrm{X}_{1}-\mathrm{X}_{\mathrm{n}}=$ independent variables (demographic and institutional characteristics).

\section{RESULTS AND DISCUSSION}

\section{Socio-Economic Characteristics of Respondents}

Results of the socio-economic characteristics of the respondents were presented in Table 1, the data showed that $77.8 \%$ of the respondents were males while $22.2 \%$ of the respondents were females. This could be attributed to the fact that most households in the study areas were headed by men and women were left to take care of household chores and children. This correlate with Woldu, et. al [6] who reported that 91\% of goat owners in Ethiopia are males. On the basis of age classification, it is revealed that $40.7 \%$ of the respondents were between the

\begin{tabular}{|c|c|c|}
\hline Socio-economic characteristics & $\mathrm{F}, \mathrm{n}=80$ & $\%$ \\
\hline \multicolumn{3}{|l|}{ Age } \\
\hline$<30$ & 14 & 17.3 \\
\hline $30-40$ & 19 & 23.5 \\
\hline $41-50$ & 33 & 40.7 \\
\hline $51-60$ & 9 & 11.1 \\
\hline 60 and above & 5 & 7.4 \\
\hline \multicolumn{3}{|l|}{ Educational level } \\
\hline No formal & 12 & 14.8 \\
\hline Primary & 32 & 39.5 \\
\hline Secondary & 28 & 34.6 \\
\hline Tertiary & 8 & 11.1 \\
\hline \multicolumn{3}{|l|}{ Sex } \\
\hline Male & 63 & 77.8 \\
\hline Female & 17 & 22.2 \\
\hline \multicolumn{3}{|l|}{ Membership of cooperative } \\
\hline Yes & 12 & 14.8 \\
\hline No & 68 & \\
\hline \multicolumn{3}{|l|}{ Source of labour } \\
\hline Self & 32 & 39.5 \\
\hline Family & 44 & 55.6 \\
\hline Hired & 3 & 3.7 \\
\hline Family and Hired & 1 & 1.2 \\
\hline \multicolumn{3}{|l|}{ Source of Credit } \\
\hline Personal & 42 & 51.9 \\
\hline Family and friends & 24 & 30.9 \\
\hline commercial bank & 3 & 3.7 \\
\hline cooperative bank & 5 & 6.2 \\
\hline Micro Finance & 2 & 2.5 \\
\hline Money lender & 3 & 3.7 \\
\hline Government & 1 & 1.2 \\
\hline \multicolumn{3}{|l|}{ Extension agents contact } \\
\hline Yes & 15 & 18.5 \\
\hline No & 65 & 81.5 \\
\hline \multicolumn{3}{|l|}{ Frequency of visits } \\
\hline Frequently & 6 & 7.4 \\
\hline Sometimes & 9 & 11.1 \\
\hline Rarely & 65 & 81.5 \\
\hline \multicolumn{3}{|l|}{ Annual income from goat } \\
\hline$<100,000$ & 28 & 34.6 \\
\hline $100,000-300,000$ & 52 & 65.4 \\
\hline \multicolumn{3}{|l|}{ Annual income from other sources } \\
\hline$<100,000$ & 12 & 14.8 \\
\hline $100,000-300,000$ & 25 & 32.1 \\
\hline $300,001-600,000$ & 33 & 40.7 \\
\hline 600,001 and above & 10 & 12.3 \\
\hline \multicolumn{3}{|l|}{ Farming experience } \\
\hline$<10$ years & 52 & 65.4 \\
\hline 10-20 years & 21 & 25.9 \\
\hline $21-30$ years & 7 & 8.6 \\
\hline \multicolumn{3}{|l|}{ Farming system } \\
\hline Intensive & 5 & 6.2 \\
\hline Semi-Intensive & 61 & 76.5 \\
\hline Extensive & 14 & 17.3 \\
\hline \multicolumn{3}{|l|}{ No of goats } \\
\hline$<10$ & 6 & 7.4 \\
\hline 10 to 20 & 40 & 49.4 \\
\hline 21 to 30 & 20 & 24.7 \\
\hline $31-40$ & 11 & 14.8 \\
\hline 41 to 50 & 3 & 3.7 \\
\hline
\end{tabular}

Table 1: Socio-economic Characteristics

Source: Field survey, 2020.

age gap of $41-50$ years, $23.5 \%$ were in the age gap of $30-40$ years, $17.3 \%$ were in the age gap of less than 30 years and $18.5 \%$ were in the age gap of 51 years and above. The mean age was 42.4 years. However, $64.2 \%$ of the respondents fell between the 
age bracket of 30-50 years. This age category or range represents the active labor force or working population which means that a large percentage of goat farmers belong to the active working population and are still in their years of economic productivity. This result correlated with the study of Boz [7] which reported that $47.9 \%$ of goat farmers were between the ages of $35-50$ years with mean age of 45.67 years. The fact that $95 \%$ of the respondents were aged above 31 years showed a major generation gap. The generation below 30 years of age preferred to seek off-farm employment, a finding which is consistent with the general tendency of migration of youth to urban areas to find white collar jobs. In terms of educational qualification, 39.5\% of the respondents had a primary school degree, $34.6 \%$ had a secondary school degree, $11.1 \%$ had a tertiary school degree and $14.8 \%$ of the respondents had no formal education. Thus, about $74.1 \%$ of the respondents has had one form of formal education or another (at least a primary level of education) indicating that goat farmers in the study area are fairly educated. This result corroborates with Rahman et al. [8] as reported in their study that $85.71 \%$ of goat farmers have undergone at least primary level of education. The result of this study reveals sources of labour available and used by respondents showed that a bulk of the respondents about $95.1 \%$ employed both self (39.5\%) and family (55.6\%) labour while a very low percentage of $4.9 \%$ used hired labour. This implied that family labour was the main type of labour used by goat farmers in the study area and this may be attributed to the fact that there was not enough income to employ hired labour. This finding agreed with Haile [9] who stated in his study that family labour was the major source of labour used in the management of goats. The result in the table shows that a very low percentage of the respondents (14.8\%) belonged to agricultural cooperatives and $85.2 \%$ did not belong to any agricultural cooperative. This was attributed to the fact that the respondents don't have proper information about cooperatives. A high percentage of the respondents (51.9\%) sourced credit or funds from personal savings, $30.9 \%$ sourced credit from family and friends and $17.3 \%$ of the respondents sourced funds from other financial institutions This may be attributed to the fact that the interest rates on other sources are high and that they do not have enough collateral to borrow funds or source credit because most of the respondents in the study area operate on small scale goat farming. Gül et al. [10] in his study reported that an average of $25 \%$ of respondents used agricultural credits and the remaining $75 \%$ did not use agricultural credits.

From this study a very low percentage of the respondents (18.5\%) had very low contact with extension agents while a bulk of the respondents $(81.5 \%)$ had no contact with extension agents. It was also revealed that among those respondents that had contact with extension agents, $81.5 \%$ of them were rarely visited. This implied that farmers were not much aware of recent findings and modern techniques to help improve their efficiency in goat farming. Frequently organized extension programs and farmers visitation by extension agents improve farmers knowledge and experience about goat farming which in turn increase productivity and enhanced fast adoption of modern goat management practices [10]. Respondents' annual income (naira) from goat farming showed that $65.4 \%$ earn
100,000-300,000 and 34.6\% earned less than 100,000. This revealed that majority of the respondents earned more than others and this was attributed to the fact that some had more farming experience and high competence in the management practices of goats and this implied that goat farming was indeed a viable supplementary source of income. Respondents' annual income from other occupation (naira) showed that $14.8 \%$ of the respondents earned less than $100,000,32.1 \%$ earned 100,000 $300,000,40.7 \%$ earned 300,000-600,000 and only $12.3 \%$ earned above 600,000 . This result indicated that a higher percentage of the respondents in the study area have an average monthly income of which equals the minimum wage of thirty thousand naira in Nigeria. The results of the study showed from the table that majority of the respondents $(65.4 \%)$ had farming experience of less than 10 years, $25.9 \%$ had from 10-20 years farming experience and only $8.6 \%$ had above 20 years of farming experience. The average farming experience was estimated to be 7.33 years. A large percentage of the respondents $(72.5 \%)$ practiced semi-intensive system of management, $17.3 \%$ practiced extensive system of management and $6.2 \%$ practiced purely intensive system of management. This revealed that the semi-intensive system of management was a general system of management practiced by respondents in the study area. The number of goats reared or owned by the respondents showed that $49.4 \%$ of the respondents had $10-20$ goats, $24.7 \%$ had 21 30 goats, $14.8 \%$ had $31-40$ goats, $7.4 \%$ had less than 10 goats and $3.7 \%$ had above 40 goats. The average number of goats owned/reared by respondents in the study area was 18.8. This result revealed that majority of respondents in the study area practiced small scale goat farming. The low herd size may be due to financial constraints, large of labour required for operation of large herd size, lack of access to farmlands and the part-time nature of the business.

\section{Competence in Management Practices}

Table 2 shows the competence in management practices of the respondents. Under health care services, result showed high competence in selection and isolation of sick goat $(\mathrm{M}=2.53)$ and administering vaccines against CCRP and PPR $(\mathrm{M}=2.57)$. Jana et al. [11] reported that majority of the farmers (87.33\%) vaccinated their goats against major diseases like PPR and foot mouth diseases but only few farmers did not take any curative and preventive measures and this might be as a result of poor economic situation or ignorance. In housing, result showed high competence in concrete floor $(\mathrm{M}=2.51)$, dwarf walls for proper ventilation $(\mathrm{M}=2.59)$ and roofing of house to avoid undue stress $(\mathrm{M}=2.55)$. In kid management, the result showed low competence in weaning $(\mathrm{M}=1.32)$, castration $(\mathrm{M}=1.11)$, disbudding $(\mathrm{M}=1.28)$ and creeping feeding $(\mathrm{M}=1.17)$ and high competence in care of young goats after birth $(M=2.54)$. This implied that majority of respondents did not practice kid management which may be attributed to lack of knowledge and information for proper management of kids to improve growth and reduce mortality rate in kids.

The result of nutrition also low competence in supply of feed supplements $(\mathrm{M}=1.32)$, provision of sufficient balanced $(\mathrm{M}=1.44)$, supply of clean fresh water $(\mathrm{M}=1.28)$, use of mineral 
Table 2: Competence in management practices

\begin{tabular}{|c|c|c|}
\hline Management practices & Mean & Std. Dev \\
\hline \multicolumn{3}{|l|}{ Health care services } \\
\hline Selection and isolation of sick goat & 2.53 & 0.04 \\
\hline Deworming & 1.36 & 0.19 \\
\hline Dipping and spraying against ecto parasites & 1.46 & 0.52 \\
\hline Administering vaccines & 2.57 & 0.33 \\
\hline Drenching & 1.45 & 0.34 \\
\hline \multicolumn{3}{|l|}{ Housing } \\
\hline Concrete floor & 2.51 & 0.99 \\
\hline Dwarf walls for proper ventilation & 2.59 & 0.39 \\
\hline Litter materials on the floor & 1.34 & 0.72 \\
\hline Orientation should be east direction & 1.25 & 0.43 \\
\hline Fencing of pens to avoid attacks & 1.31 & 0.19 \\
\hline Roofing of house to avoid undue stress & 2.55 & 0.32 \\
\hline \multicolumn{3}{|l|}{ Kid Management } \\
\hline Weaning & 1.32 & 0.32 \\
\hline Castration & 1.11 & 0.21 \\
\hline Disbudding & 1.28 & 0.29 \\
\hline Creep feeding & 1.17 & 0.77 \\
\hline Care of young goats after birth & 2.54 & 0.32 \\
\hline \multicolumn{3}{|l|}{ Nutrition } \\
\hline Supply of feed supplements & 1.32 & 0.17 \\
\hline Provision of sufficient balanced diet & 1.44 & 0.33 \\
\hline Supply of cleaned fresh water & 1.28 & 0.29 \\
\hline Provision of silage, haylage and concentrates & 2.57 & 0.22 \\
\hline Use of minerals salt licks & 1.19 & 0.44 \\
\hline Good pasture areas & 2.56 & 0.45 \\
\hline \multicolumn{3}{|l|}{ Breeding programmes } \\
\hline Breeding systems & 1.22 & 0.12 \\
\hline Mating systems & 1.21 & 0.18 \\
\hline Selection of goat with desirable traits & 2.93 & 0.32 \\
\hline Culling & 2.52 & 0.22 \\
\hline \multicolumn{3}{|l|}{ Identification } \\
\hline Ear Tagging & 1.23 & 0.19 \\
\hline Branding & 1.21 & 0.91 \\
\hline Ear Notching & 1.01 & 0.33 \\
\hline \multicolumn{3}{|l|}{ Farm Hygiene } \\
\hline Presence of foot dip & 1.19 & 0.32 \\
\hline Collection and disposal of goat faeces & 1.43 & 0.09 \\
\hline Regular cleaning and disinfecting of pens & 2.51 & 0.32 \\
\hline Washing of feeds and water trough & 2.53 & 0.12 \\
\hline Screening of pens against insects and pests & 1.49 & 0.29 \\
\hline \multicolumn{3}{|l|}{ Doe Management } \\
\hline Flushing & 1.33 & 0.29 \\
\hline Care of pregnant doe & 2.57 & 0.43 \\
\hline Kidding & 2.55 & 0.34 \\
\hline Milking & 1.09 & 0.21 \\
\hline Steaming up & 1.03 & 0.18 \\
\hline \multicolumn{3}{|l|}{ Record keeping } \\
\hline Sales and income records & 1.45 & 0.32 \\
\hline Breeding records & 1.49 & 0.31 \\
\hline Expense records & 2.56 & 0.36 \\
\hline Identification records & 1.32 & 0.21 \\
\hline \multicolumn{3}{|l|}{ Milking } \\
\hline Care of udder & 1.22 & 0.32 \\
\hline Storage of milk & 1.01 & 0.29 \\
\hline cleaning of teats & 1.22 & 0.43 \\
\hline drying up & 1.21 & 0.39 \\
\hline \multicolumn{3}{|l|}{ Buck Management } \\
\hline Servicing & 2.56 & 0.11 \\
\hline Increase feed ration before mating & 2.54 & 0.21 \\
\hline Selection & 1.13 & 0.33 \\
\hline Dehorning & 1.22 & 0.38 \\
\hline storage of feed & 1.19 & 0.34 \\
\hline hoof ww & 1.27 & 0.34 \\
\hline
\end{tabular}

(Contd...)
Table 2: (Continued...)

\begin{tabular}{lcc}
\hline Management practices & Mean & Std. Dev \\
\hline processing of leather & 1.05 & 0.22 \\
marketing of goats and their products & 1.12 & 0.19 \\
\hline
\end{tabular}

Source: Field survey, 2020.

Mean $\geq 2.0=$ High competence.

salt licks $(M=1.19)$ and good pasture areas $(M=1.56)$ and high competence in only provision of silage and concentrates $(\mathrm{M}=2.57)$. This result implied that majority of the respondents were not consistent or competent in these management practices but were consistent in the provision of silage and concentrates because their mean was greater than the benchmark of 2.0. Woldu et al. [6] reported in his work that only $18 \%$ of farmers purchased additional feed supplements, the major feedstuffs purchased were crop residues mainly used for fattening of goats. From the table below, result under farm hygiene showed that presence of foot dip $(\mathrm{M}=1.19)$, screening of pens against insects and pests $(\mathrm{M}=1.49)$ and washing of feed and water trough $(\mathrm{M}=1.43)$ had low competence but collection and disposal of faeces $(\mathrm{M}=$ 2.43) and regular cleaning and disinfecting of pens $(M=2.51)$ had high competence. Result from doe management showed that flushing $(\mathrm{M}=1.33)$, milking $(\mathrm{M}=1.09)$ and steaming up $(\mathrm{M}=1.03)$ had low competence and high competence in care of pregnant doe $(\mathrm{M}=2.57)$ and kidding $(\mathrm{M}=2.55)$. Results from milking showed low competence in care of udder $(\mathrm{M}=1.22)$, storage of milk $(\mathrm{M}=1.01)$, cleaning of teats $(\mathrm{M}=1.22)$ and drying up $(\mathrm{M}=1.21)$. This revealed that farmers in the study area did not milk their goats; this may be as a result of lack of interest, ignorance and inadequate knowledge about the process and economic benefits of milking goats. Result from record keeping showed low competence in sales and income records $(\mathrm{M}=1.45)$, breeding records $(\mathrm{M}=1.49)$ and identification records $(\mathrm{M}=1.32)$ and high competence in expense records $(\mathrm{M}=2.56)$. This revealed that the farmers recorded all the costs incurred in the course of goat production; this is usually undertaken by the farmers to know if they are making profit or not. Result from the study showed low competence in storage of feeds $(\mathrm{M}=1.99)$ and hoof trimming $(\mathrm{M}=1.27)$.

\section{Level of Competence in all the Management Practices}

In Figure 1 below which shows the respondents' level of competence in goat management practices, it is seen that a very large percentage of the respondents $(70.2 \%)$ have very low competence in goat keeping and management practices which is largely due to some factors which includes lack of information, poor knowledge and technical knowhow or skill and also poor access to extension agents. This could be attributed to the low production level experienced by the farmers as their level of competence is low which will result in low revenue for the goat farmers and a continuous poverty cycle amongst the farmers.

\section{Constraints Faced by Respondents}

Results in Table 3 shows that the major constraints or problems faced by respondents in goat farming were difficulty in keeping records $(M=3.01)$, lack of feed supplements $(M=3.59)$, 
Incidence of ecto parasite $(\mathrm{M}=3.91)$, absence of healthcare services $(M=3.47)$, loss of goat by theft $(M=3.28)$, lack of extension services $(M=3.97)$, lack of credit facilities $(M=3.19)$, lack of information $(\mathrm{M}=3.04)$, lack of pasture and graze land $(\mathrm{M}=4.12)$, poor goat nutrition $(\mathrm{M}=3.16)$, Inadequate farmlands $(M=3.02)$ and attack by predators $(M=3.76)$. These constraints were considered serious by the respondents as their means were above 3.0 This result agreed with the findings of Kumawat et al. [12] and Tanwar [13] who reported that the major constraints faced by goat farmers were lack of knowledge, shrinking or diminishing grazing lands, lack of veterinary services in villages and poor goat nutrition. Similar findings were reported by Kumar et al. [14] and Narmatha et al. [15] who reported scarcity of green folder and of diminishing grazing areas as major challenges faced by goat farmers. Rahman et al. [8] reported that major problems that farmers faced lack of grazing lands, lack of improved breeds of goat, lack of housing facilities, lack of credit, inadequate veterinary services, lack of extension services and theft of goat. Jana et al. [11] reported that lack of knowledge about scientific goat rearing as well as shortage of space for farming were part of the major constraints faced by

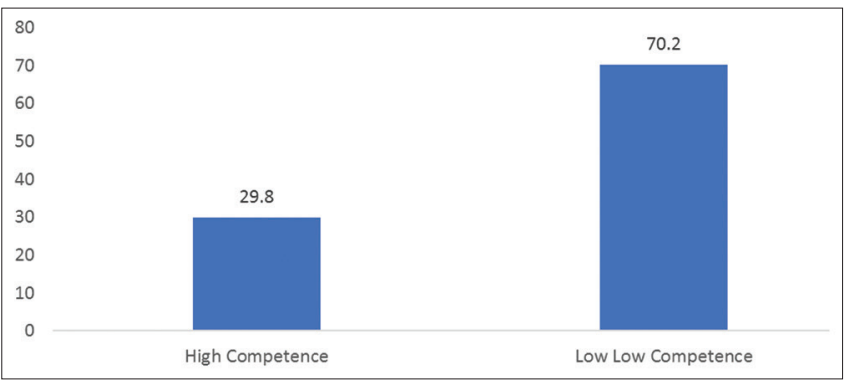

Figure 1: Respondents' Level of competence in goat management practices

Table 3: Constraints Faced by Respondents

\begin{tabular}{lcc}
\hline Constraints & Mean & Std. Dev \\
\hline Selection of goat breeds & 2.54 & 0.44 \\
Difficulty in records keeping & 3.01 & 0.19 \\
Lack of feed supplements & 3.59 & 0.39 \\
Incidence of intestinal worms & 2.65 & 0.61 \\
Poor growth & 2.41 & 0.47 \\
Incidence of ecto-parasites & 3.91 & 0.05 \\
Low demand for goat & 1.31 & 0.43 \\
Absence of healthcare services & 3.47 & 0.61 \\
Loss of goat by theft & 3.28 & 0.84 \\
High mortality rate & 2.69 & 0.41 \\
Adverse weather condition & 2.54 & 0.51 \\
Lack of extension services & 3.97 & 0.44 \\
Inadequate labour supply & 2.65 & 0.32 \\
lack of credit facilities & 3.19 & 0.49 \\
Poor sales and low prices & 2.37 & 0.17 \\
Poor farm hygiene & 2.33 & 0.48 \\
Lack of information & 3.04 & 0.15 \\
Lack of pasture and graze land & 4.12 & 0.09 \\
Poor goat nutrition & 3.16 & 0.29 \\
Lack of farm inputs & 2.18 & 0.51 \\
Inadequate farmland & 3.02 & 0.45 \\
Attack by predators & 3.76 & 0.54 \\
Poor marketing & 2.29 & 0.48 \\
\hline
\end{tabular}

Source: Field survey, 2020.

Mean $\geq 3.0=$ Serious constraints. goat farmers. Haile [9] reported in his work that disease and attack by predators are major constraints faced by famers in his study area.

\section{Estimate of binary logistics regression}

Logistic regression model was used to test our hypothesis stated "There is no significant relationship between the institutional characteristics and farmers' level of competence in the management practices" Result of logistic regression analysis for hypothesis testing is presented in Table 4 . The table revealed that four of the explanatory or independent variables were found to have significant effect on the level of competence in management practices of the respondents. These variables were membership of cooperatives $(Z=3.19)$, source of labour $(Z=2.50)$, source of credit $(Z=2.31)$ and income gotten from goat farming ( $Z$ $=3.047)$. Membership of cooperatives had a $p$ value of 0.01 which was significant at $1 \%$ this implies that it had a significant effect on the competence level in management practices. From this study, since majority of the respondents did not belong to cooperatives and the overall level of competence in management practices was very low, the implication is that non membership in cooperative had a negative significant effect on the level of competence management practices of respondents. This means that non membership in cooperative also resulted in very low competence level in management practices of respondents. Source of labour had a p value of 0.05 which was significant at $5 \%$, it showed that it had a positive significant effect on the level of competence in management practices. Results from this study showed that a large percentage of the respondents used family labour in goat farming and agreed that large family size equal to increase in family labour. The implication is that since the average household size is 7 and is quite large, it equals large family labour which in turn results in efficiency and high level of competence in management practices. Source of credit had a $\mathrm{p}$ value of 0.03 which was significant at $5 \%$, this showed that the source of credit had a significant effect on the level of competence in management practices. The source of credit of most respondents was personal savings which revealed that it was the most reliable source of credit for financing the business. This implies that an increase in personal savings will increase income available to carry out management practices in goat farming which will result in high productivity and increased level of competence.

Table 4: Results of binary logistic regression sowing the relationship between the institutional characteristics and farmers' level of competence in the management practices

\begin{tabular}{|c|c|c|c|c|c|}
\hline Variable & Odd ratio & Std. Error & Z & $\mathrm{P}>|\mathrm{z}|$ & Decision \\
\hline $\begin{array}{l}\text { Membership of } \\
\text { cooperative }\end{array}$ & 2.59 & 0.91 & 3.19 & 0.01 & S \\
\hline Source of labour & 3.72 & 0.37 & -2.50 & 0.05 & S \\
\hline Source of credit & 2.38 & 0.08 & 2.31 & 0.03 & S \\
\hline $\begin{array}{l}\text { Contact with ext. } \\
\text { agents }\end{array}$ & 1.41 & 0.15 & 1.07 & 0.59 & NS \\
\hline Income from goat & 3.99 & 0.41 & 3.047 & 0.01 & S \\
\hline $\begin{array}{l}\text { Income from others } \\
\text { sources }\end{array}$ & 1.83 & 0.15 & 1.94 & 0.65 & NS \\
\hline
\end{tabular}

Regression at $1 \%$ and $5 \%$ level of significance.

Source: Computed from Field survey, 2020. 
The income gotten from goat farming had a p value of 0.01 which was significant at $1 \%$. This shows that the income gotten from goat farming has a significant effect on the level of competence in management practices. Most respondents make an annual income of 100,000 - 300,000 naira from goat farming which from a small-scale production that most of them were involved in was considered suitable source of supplementary income for both full time and part time farmers. This income is somewhat enough to carry out sustainable management practices in goat farming.

\section{CONCLUSION}

It is evident that goat farmers in the study area possess low competence in goat farming management practices, which is evident in the low production level of goat product in the study area Lack of extension services, lack of pasture and graze land and prevalence of ecto-parasites are some of the major constraints faced by goat farmers in the study area. The hypothesis testing reveals There is significant relationship between the institutional characteristics and farmers' level of competence in the management practice of goat farmers. It is therefore recommended that Programmes should organized by government to improve the management practices by introducing modern methods, also encouraging goat farmers to form or belong to organizations such as cooperatives among others, the agricultural extension services should be strengthened to improve management skills of farmers.

\section{REFERENCES}

1. Asogwa, V.C (2013). Entrepreneurial competencies in goat production for enhancing the income of teachers of agriculture in secondary schools in Enugu state Nigeria. International Journal of Advanced and Innovative Research 2(10) 2278-7844. www.advanceresearchlibrary. com/ijairp17.

2. Friday, N. N. (2004) An Assessment of goat Production and Utility in Kogi State. Unpublished M. Sc thesis, Department of Agricultural Extension, University of Nigeria, Nsukka.

3. Ogba, O.A. (2013). Animal production for schools and college.
Abakaliki: Smile publishers.

4. Boniface, k., Patrick, M. and Camilus, A. (2003). Farmers dairy goat production handbook: Nairobi. The media company Kenya www. milkproduction.com.global

5. Khalid M. (2013), The Rise of the South - Human Progress in a Diverse World. Human Development report. United Nation Developmental Programme (UNDP).

6. Woldu. T., Markemann. A., Reiber. C., Philipp C., and A. Muth (2016). Optimising Contributions of Goat Farming to Household Economic Success and Food security in Three Production systems in Ethiopia, Anne Valle Zárate University of Hohenheim, Institute of Agricultural Sciences in the Tropics. 1612-9830.

7. Boz, Ismet. (2015). Adoption of innovations and best management practices by goat farmers in eastern Mediterranean Region of Turkey. Journal of Agricultural Extension and Rural Development. 7. 229-239.

8. Rahman. M., Hossain. M., and Momen Miah, M. A., (2013). Poverty Reduction and Livelihood Improvement of Women Through Goat Rearing. Department of Agricultural Extension Education, Bangladesh Agricultural University (BAU), Mymensingh -2202, Bangladesh.

9. Haile, S. (2012). Impact of Goat Development Project on Livelihood Assets: the case of Northern Red Sea Region in Eritrea. A Research Project Submitted to Van Hall sLarenstein University of Applied Sciences in Partial Fulfilment of the Requirements for the Award of Master's Degree in Management of Development.

10. G. M., Demircan, V., Yilmaz. M., Yilmaz, H., and S. Demirel, (2016). Technical efficiency of goat farming in Turkey: a case study of Isparta province University, Faculty of Agriculture, Department of Agricultural Economics, Isparta, Turkey. Eastern Mediterranean Agricultural Research Institute, Adana, Turkey.R. Bras. Zootec., 45(6):328-335.

11. Jana C, Rahman FH, Mondal SK, Singh AK (2014) Management Practices and Perceived Constraints in Goat Rearing in Burdwan district of West Bengal. Indian Res. J. Ext. Edu. 14(2):107-110.

12. Kumawat, M., Uddin, A., Bhinda, R., Lal Khichar, S., and Jat, G.R. (2017). Constraints Faced by Farmers in Goat Rearing Practices in Jaipur District of Rajasthan, India. International Journal of Current Microbiology and Applied Sciences 6(12): 942-944.

13. Tanwar, P. S., (2011), "Constraints Perceived by Goat Keepers in Adoption of Goat Husbandry Practices in Semi-Arid Rajasthan", Journal of Community Mobilization and Sustainable Development 6(1): 108-111.

14. Kumar, V., Braj M., Dixit, A.K., Singh, khushyal, Kumar C., U.B. and Goel, A.K. (2015). Goat farming status: A benchmark survey in adopted village of Mathura district of Uttar Pradesh. Indian Journal of Small Ruminants, 21(1):158-160.

15. Narmatha, N., Sakthivel, K.M., Uma, V. and Akila, N., (2013). Adoption and Constraints in Improved Goat Rearing Practices. Indian Journal of Animal Research, 47(6): 547-550. 